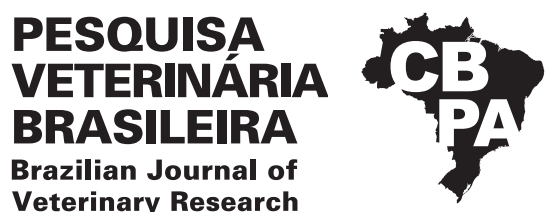

Pesq. Vet. Bras. 40(5):355-359, May 2020 DOI: 10.1590/1678-5150-PVB-6603

Original Article

Veterinarv Research

ISSN 0100-736X (Print)

ISSN 1678-5150 (Online)

\title{
Actinobacillosis outbreak in cattle with clinical manifestation of hippopotamus-like face ${ }^{1}$
}

\author{
Haide Valeska Scheid ${ }^{2}$ (D), Pablo Estima-Silva², Francielle Liz Monteiro², \\ Lucas S. Marques², Ana Carolina B. Coelho ${ }^{3}$, Marcelo de Lima ${ }^{4}$, \\ Silvia R.L Ladeira ${ }^{5}$ and Ana Lucia Schild ${ }^{5 *}$ (D)
}

\begin{abstract}
Scheid H.V., Estima-Silva P., Monteiro F.L., Marques L.S., Coelho A.C.B Lima M., Ladeira S.R.L. \& Schild A.L. 2020. Actinobacillosis in cattle with clinical manifestation of hippopotamus-like face. Pesquisa Veterinária Brasileira 40(5):355-359. Laboratório Regional de Diagnóstico, Faculdade de Veterinária, Universidade Federal de Pelotas, Campus Universitário s/n, Capão do Leão, RS 96010-900, Brazil. E-mail: alschild@terra.com.br

Actinobacillosis outbreak with clinical manifestation of hippopotamus-like face observed in a property located in the municipality of Capão do Leão, Southern Brazil, in September 2016, is described. The cattle herd remained for most of the year in rice stubble. When these areas were occupied with new crops, they were transferred to areas where there were small native forests. Three cattle were affected. They presented a volume increase in the nasolabial and maxillary region, and there was also regional lymph node swelling. The evolution of the disease occurred in approximately six months. In tissue fragments collected for culture, Actinobacillus lignieresii was isolated. The diagnosis was based on clinical findings, histopathological evaluation characterized by the presence of piogranulomas with Splendore Hoeppli reaction in its center, bacterial isolation, and identification of A. lignieresii by polymerase chain reaction (PRC) and genetic sequencing.
\end{abstract}

INDEX TERMS: Actinobacillus lignieresii, diseases of cattle, hippo face, molecular diagnostics, cattle.

RESUMO.- [Actinobacilose em bovinos com manifestação clínica de cara de hipopótamo.] Descreve-se um surto de actinobacilose com manifestação clínica de cara de hipopótamo diagnosticado em uma propriedade localizada no município do Capão do Leão, Rio Grande do Sul em setembro de 2016. Os bovinos permaneciam durante a maior parte do ano em restevas de arroz e quando as áreas eram ocupadas com novas lavouras eram transferidos para áreas onde havia pequenas matas nativas. Foram afetados três bovinos adultos que apresentavam aumento de volume na região nasolabial e

\footnotetext{
${ }^{1}$ Received on February 19, 2020.

Accepted for publication on March 5, 2020.

${ }^{2}$ Graduate Studies Program in Veterinary, Faculdade de Veterinária, Universidade Federal de Pelotas (UFPel), Campus Universitário Capão do Leão, Capão do Leão, RS 96010-900, Brazil.

${ }^{3}$ Faculdade de Veterinária, Centro Universitário Ritter dos Reis (UniRitter), Rua Orfanotrofio 555, Alto Teresópolis, Porto Alegre, RS 90840-440, Brazil.

${ }^{4}$ Laboratório de Virologia e Imunologia (LabVir), Faculdade de Veterinária, Universidade Federal de Pelotas (UFPel), Campus Universitário Capão do Leão, Capão do Leão, RS 96010-900, Brazil.

${ }^{5}$ Laboratório Regional de Diagnóstico (LRD), Faculdade de Veterinária, Universidade Federal de Pelotas (UFPel), Campus Universitário Capão do Leão, Capão do Leão, RS 96010-900, Brazil. *Corresponding author: alschild@terra.com.br
}

maxilar e havia, também, tumefação dos linfonodos regionais. A evolução da enfermidade era de aproximadamente seis meses. Nos fragmentos coletados para cultura houve isolamento de Actinobacillus lignieresii. 0 diagnóstico foi baseado nos achados clínicos, na avaliação histopatológica caracterizada pela presença de piogranulomas com reação de Splendori Hoeppli no centro, no isolamento bacteriano, identificação de Actinobacillus lignieresii por reação em cadeia da polimerase (PRC) e sequenciamento genético.

TERMOS DE INDEXAÇÃO: Actinobacillus lignieresii, bovinos, cara de hipopótamo, diagnóstico molecular.

\section{INTRODUCTION}

Actinobacillosis is a cosmopolitan disease of sporadic occurrence characterized by the inflammatory piogranulomatous reaction. The disease affects cattle and less commonly sheep, pigs and horses (Andreazza et al. 2013, Caffarena et al. 2017). In ruminants, it is caused by Actinobacillus lignieresii, gramnegative aerobic bacterium, present in the oral cavity, upper respiratory tract, and rumen (Andreazza et al. 2013).

Actinobacillus infection occurs due to mucosal and epidermis lesions allowing the bacteria to penetrate in injured tissues. 
The bacteria can affect regional lymph nodes and other organs by lymphatic or hematogenic route (Tessele et al. 2014). In the southern region of Brazil, cattle are placed in areas of rice and soybean cultivation after harvest, providing appropriated epidemiological conditions to the appearance of cases, since in the stubbles remain fibrous and dry stalks that can injure the oral mucosa of animals (Andreazza et al. 2013, Margineda et al. 2013). The disease is often diagnosed in cattle in the southern region of Brazil, especially in the subclinical form in slaughter animals, and is often confused with tuberculosis (Tessele et al. 2014, Schild et al. 2018).

Actinobacillosis, in its classical form, presents with lesions in the tongue and regional lymph nodes of the head and neck (Andreazza et al. 2013, Caffarena et al. 2017). Atypical cases are described by several authors and characterized by skin lesions (Margineda et al. 2013), respiratory system lesions (Peli Agnelo et al. 2009), lymph nodes lesions (Caffarena et al. 2017) and generalized lymph nodes and organs lesions (Kasuya et al. 2017). Lesions on the lips, palate, pharynx, nasal pits and face, when diffuse lead to a clinical picture called hippo-like face. This form of the disease, although mentioned by some authors, is not often described (Mondadori et al. 1994).

The diagnosis of actinobacillosis is based on lesions characteristic of the disease such as the presence of multiple firm and yellowish nodules surrounded by fibrous tissue and deposition of immunocomplexes known as a Splendore Hoeppli (Margineda et al. 2013, Tessele et al. 2014). However, molecular identification and genetic sequencing is important in the elaboration of the diagnosis especially in atypical cases of the disease (Caffarena et al. 2017).

The aim of this paper was to describe the epidemiology and pathology of an outbreak of actinobacillosis with clinical manifestation of hippo-like face, discussing the possible routes of infection, as well as performing the molecular identification of the A. lignieresii.

\section{MATERIALS AND METHODS}

In September 2016, three cattle belonging to a property located at the municipality of Capão do Leão, southern Brazil, showed clinical signs of increased face volume, mainly in the nasolabial and maxillary region. Epidemiological and clinical data from the veterinarian responsible for the property were obtained. Biopsies in two cattle for histopathological examination and microbiological culture were performed. An affected steer was euthanized and necropsied. Fragments of all organs were fixed in $10 \%$ buffered formalin, routinely processed and stained with hematoxylin and eosin (HE). Tissue samples were sent to the bacteriology laboratory of Laboratório Regional de Diagnóstico (LRD-UFPel), being sown in blood agar culture media and MacConkey.

Paraffin blocks containing biopsy and necropsy material and bacterial culture isolated from clinical specimens were sent to the virology and immunology laboratory of the Faculdade de Veterinária da Universidade Federal de Pelotas (LabVir UFPel) for molecular identification of the agent and genetic sequencing.

Construction and analysis of primers. Primers for amplification of an 180 base pair (bp) fragment of Actinobacillus lignieresii 16S ribosomal RNA were constructed in the OligoPerfect ${ }^{\mathrm{TM}}$ software (Thermo Fischer). The partial sequence A. lignieresii strain NCTC 4189 16S ribosomal RNA gene, deposited in GenBank under code AY362892, was used for the construction. Primers Al_F: 5 'ACG GGT GAG TAA TGC TTG GG 3' and Al_R: 5 'GCT AGA GAT CGT CGG CTT GG
3 ' were tested on the BLAST primer ${ }^{6}$ and target the microorganisms A. lignierisii, Actinobacillus pleuropneumiae, Actinobacillus suis, Haemophilus haemolyticus, Haemophilus influenzae, Glaesserella parasuis and Conservatibacter flavescens. Alignment of these sequences was performed in BioEdit Sequence Alignment Editor Software version 7.0.5.3, with nucleotide difference between the sequences being observed (Fig.1). By using this strategy, it was possible to differentiate $A$. lignieresii from other microorganisms at the molecular level, by analysis of the amplified fragment with the Al_F and Al_R primers.

DNA extraction and PCR. DNA extraction from bacterial colonies isolated from animal tissue samples and paraffin blocks containing biopsy and necropsy tissue using DNAzol ${ }^{\mathrm{TM}}$ reagent (Thermo Fischer) and ReliaPrep ${ }^{\mathrm{TM}}$ FFPE gDNA MiniPrep System kit (Promega), respectively, both according to the manufacturer's recommendations was performed. The extracted DNA was used in the polymerase chain reaction (PCR) for partial amplification of the Actinobacillus lignieresii 16S ribosomal RNA gene. PCR was performed using 100-200ng extracted DNA, 1x GoTaq ${ }^{\circledR}$ Colorless Master Mix (Promega) and $0.4 \mu \mathrm{M}$ of each primer. The conditions were: $94^{\circ} \mathrm{C}$ for 5 minutes, 35 cycles of 94,50 and $72^{\circ} \mathrm{C}$ for 30 seconds each, and $72^{\circ} \mathrm{C}$ for 7 minutes. The PCR product was developed on $2 \%$ agarose gel and visualized in UV light after electrophoresis. Product purification was performed using the PureLink ${ }^{\circledR}$ Quick Gel Extraction and PCR Purification Kit (Thermo Fischer).

Sequence analysis. The purified PCR product in quadruplicate using BigDye Terminator v3.1 Cycle Sequencing (Thermo Fischer) was sequenced. The results were analyzed using the Staden program (Staden 1996) to obtain the quadruplicate consensus sequence.

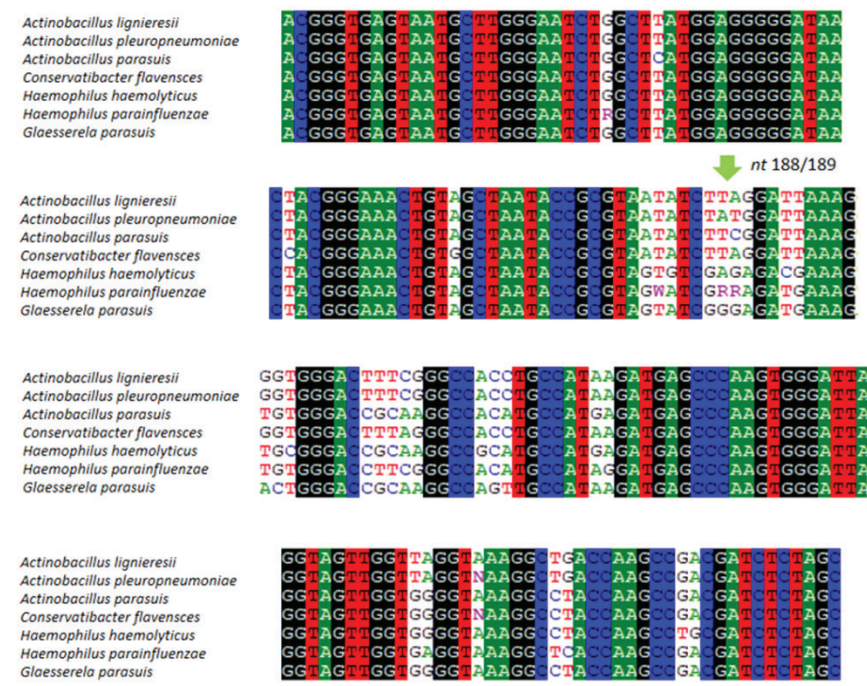

Fig.1. Actinobacillosis in cattle with clinical manifestation of hippopotamus-like face. Alignment of target sequences (primers Al). Actinobacillus lignieresii LRD16855 (sequenced sample), A. lignieresii strain NCTC 4189 (AY362892), Actinobacillus pleuropneumoniae strain Shope 4074 (NR_04475), Actinobacillus suis strain JCM 2433 (LC383928), Haemophilus haemolyticus strain CIP 103290 (NR_104930), Haemphilus parainfluenzae ATCC 33392 strain CCUG 12836 (NR_042878), Glaesserella parasuis strain CCUG 3712 (NR_042879) e Conservatibacter flavenscens strain CCUG 24852 (NR_159347).

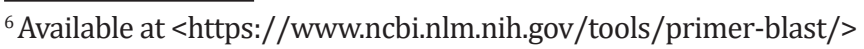


Alignment with GenBank deposited sequences and the identity matrix were performed in the BioEdit Sequence Alignment Editor Software.

\section{RESULTS}

The three cattle affected out of 321 animals were Montana breed, approximately two years old. Cattle remained for most of the year in rice stubbles, and when the areas were occupied with new crops, cattle were transferred to small native forest areas. A gradual increase in the volume of the face, which stretched from the lips to the lateral portion of the jaw and snout were observed (Fig.2). There was also tumefaction of regional lymph nodes. The skin of the nostril region was thick, peeled, and hairless. The time of evolution of the lesions was approximately six months, and progressive weight loss was observed. The enlarged lymph nodes of the head and neck often observed in cattle at the farm improve with treatment with potassium iodide and penicillin. It is noteworthy that a case of actinobacillosis in the tongue (wood tongue) and lymph nodes of the head and neck was diagnosed at the same farm in the previous year (Schild et al. 2017).

At necropsy lips, nostrils and face were increased in volume and the skin was thick. There was an intense proliferation of connective tissue interspersed by small yellow nodules in the buccinator muscle. In the anterior area of the palate, one centimeter of diameter ulcer was observed (Fig.3). The submandibular, retropharyngeal, and parotid lymph nodes were enlarged and had yellowish nodules wrapped with whitish fibrous tissue.

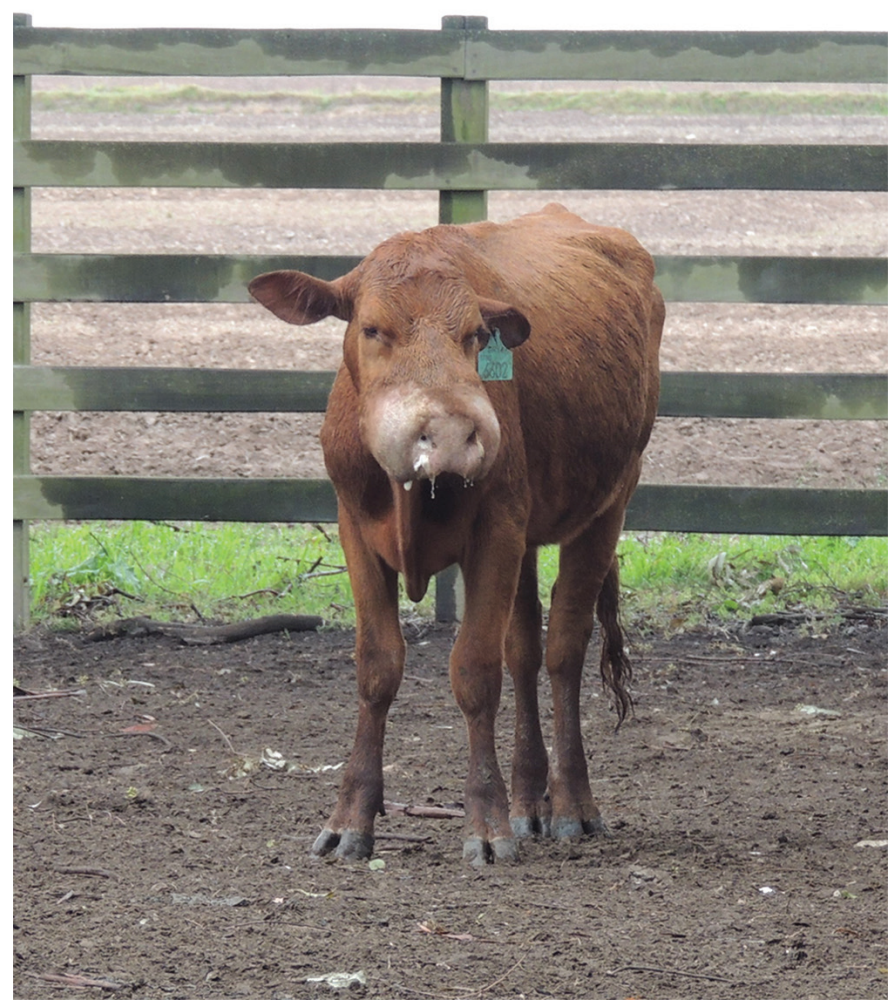

Fig.2. Actinobacillosis in cattle with clinical manifestation of hippopotamus-like face. There is an enlargement of the face affecting the nose and buccinator muscle. There are alopecia and peeling of the skin and serous to mucous nasal discharge.
Histologically, in the subcutaneous tissue and between muscle fibers of the affected region there were numerous pyogranulomas with central necrosis and presence of eosinophilic material forming rosettes (Splendore Hoepli) (Fig.4). These areas were surrounded by neutrophils, plasmocytes, macrophages, and giant cells. Proliferated fibrous connective tissue involved all pyogranulomas. The lesions extended to the nostrils and lips, in which the epidermis was thick and peeled. Small colonies of gram-negative bacteria, whose biochemical tests resulted inconclusively were isolated in bacteriological cultures. This allowed the identification only of the genus as Actinobacillus spp.

Paraffin material and bacterial colonies isolated were positive in PCR for ribosomal RNA gene 16S de Actinobacillus lignieresii (primers Al). The sequence obtained was compared with sequences deposited in GenBank that amplify with the

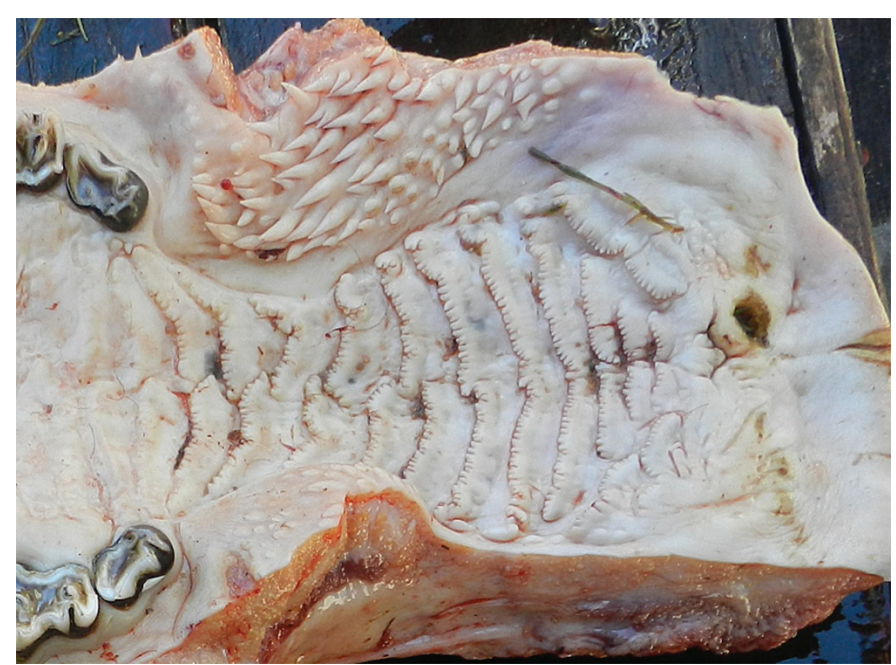

Fig.3. Actinobacillosis in cattle with clinical manifestation of hippopotamus-like face. An ulcer is in the anterior portion of the palate.

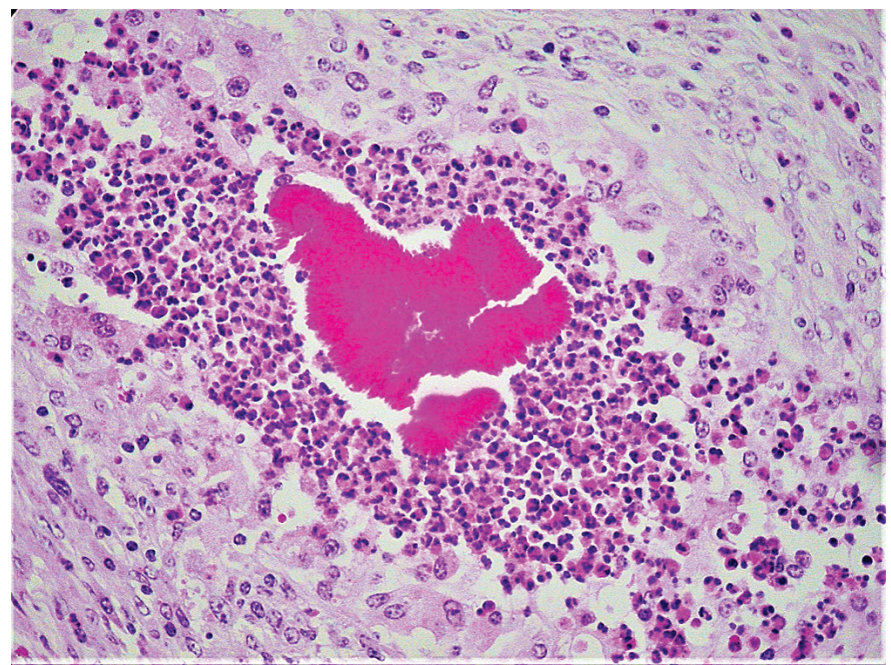

Fig.4. Actinobacillosis in cattle with clinical manifestation of hippopotamus-like face. Pyogranulomatous lesion in subcutaneous tissue with central necrosis, neutroplhils, macrophages and lynfocites and eosinophilic material forming rosettes (Splendore Hoeppli). HE, obj.40x. 
Table 1. Identity percentage of target genetic sequencing with Actinobacillus lignieresii (primers Al)

\begin{tabular}{|c|c|c|c|c|c|c|c|c|}
\hline \multicolumn{9}{|c|}{ Strains (\% identity) } \\
\hline Strains & $\mathrm{A}^{*}$ & B & $\mathrm{C}$ & $\mathrm{D}$ & E & $\mathrm{F}$ & G & $\mathrm{H}$ \\
\hline $\mathrm{A}^{*}$ & ID** & 100 & 98.3 & 92.3 & 86.8 & 92.3 & 89.6 & 95.6 \\
\hline $\mathrm{C}$ & 98.3 & 98.3 & ID & 91.2 & 86.8 & 91.8 & 89.0 & 95.0 \\
\hline D & 92.3 & 92.3 & 91.2 & ID & 92.8 & 90.1 & 93.4 & 93.4 \\
\hline G & 89.6 & 89.6 & 89.0 & 93.4 & 93.4 & 91.2 & ID & 90.7 \\
\hline $\mathrm{H}$ & 95.6 & 95.6 & 95.0 & 93.4 & 87.9 & 89.6 & 90.7 & ID \\
\hline
\end{tabular}

${ }^{*} \mathrm{~A}=$ A. lignieresii (sequenced sample LRD 16855), B = A. lignieresii strain NCTC 4189 (AY362892), C = Actinobacillus pleuropneumoniae strain Shope 4074 (NR_04475), $\mathrm{D}=$ Actinobacillus suis strain JCM 2433 (LC383928), $\mathrm{E}=$ Haemophilus haemolyticus strain CIP 103290 (NR_104930), F = Haemphilus parainfluenzae ATCC 33392 strain CCUG 12836 (NR_042878), G = Glaesserella parasuis strain CCUG 3712 (NR_042879, H = Conservatibacter flavenscens strain CCUG 24852 (NR_159347); ** ID= identity.

primers Al_F and Al_R. The identity of 100\% was obtained with the A. lignieresii (Table 1). The identity of $98.3 \%$ was obtained with the Actinobacillus pleuropneumoniae, due to differences in nucleotides 80 and 81 . The identity of the samples with the other microorganisms ranged from $86.8 \%$ to $95.6 \%$, and a difference can be observed between several nucleotides of the sequences (Fig.1).

\section{DISCUSSION}

Actinobacillosis, in the clinical form of a hippo-like face, described in the present study, is rare. The disease was characterized mainly by diffuse lesions on the lips, nostrils and face. In the present case, this clinical manifestation likely is related to the ulcerative lesion observed on the necropsied cattle palate. This lesion probably occurred as a result of the permanence of cattle in a native forest area. Small shrubs and fragments of branches, which due to stiffness and size could cause more easily injuries in this region of the oral cavity. Ulcers around the molar teeth were the entry route of infection in hippo-like face cases (Anderson et al. 1990, Turni et al. 2019), which was not present in cattle of this report, suggesting a different port of entry for the agent. The fact that the histological lesions were observed mainly in the subcutaneous tissue of the face and snout, does not rule out the possibility that the lesion was started by penetration of the agent into small lesions in the skin and/or nasal mucosa. In the property, the form of the disease affecting the head lymph nodes is frequent and, therefore, the environment is contaminated by the microorganism. Other authors describing the cutaneous form of the disease, mention environmental contamination as an important factor for the occurrence of different manifestations of the disease (Cahalan et al. 2012).

It has been mentioned that younger animals would be more predisposed to the development of the disease, especially due to the exchange in dentition that would favor infection (Rycroft \& Garside 2000), however, several outbreaks are reported in adult animals that have complete dentition (Dhand et al. 2003). There were no lesions in dental alveoli or the adjacent gums in necropsied cattle, which would rule out the possibility of infection by this route. In a case of atypical lymphatic actinobacillosis described, the possibility of penetrating the agent through the intact mucosa and infection of regional lymph nodes from where the bacteria would spread via the lymphatic due to suppuration is mentioned (Caffarena et al. 2017).

DNA sequenced from the bacterial colony isolated from the tissues of affected cattle presented $100 \%$ identity with the Actinobacillus lignieresii, unequivocally proving the association of this bacterium in the etiology of the disease. It has been described that bacterial identification of the agent in chronic lesions or in animals treated with antibiotics can be difficult, requiring the use of molecular diagnostic techniques for the detection of Actinobacillus (Milne et al. 2001). The methodology developed in the present study is an auxiliary tool and indispensable for the diagnosis and precise identification of the agent in new outbreaks, especially in atypical cases of the disease.

A differential diagnosis should include other diseases that cause an increased volume of the face, such as infection by Mannheimia granulomatis, bacterium a condition colloquially known as lechiguana described in the southern region of Rio Grande do Sul, Minas Gerais and São Paulo (Ladeira et al. 1996, Birgel et al. 1999). In this case, however, the swelling is very firm, and occurring mainly over the scapula and its surroundings, and the histological lesion is characterized by extensive fibrosis in the subcutaneous tissue (Riet-Correa et al. 1992). Other diseases such as nocardiosis, which causes pyogranulomatous lesions in the skin and actinomycosis characterized by pyogranulomatous osteomyelitis, especially in the mandible (Relun et al. 2019), should also be differentiated from actinobacillosis.

\section{CONCLUSIONS}

Actinobacillosis with clinical manifestation of hippopotamuslike face, although unusual, occurs with epidemiological conditions similar to the others forms of the disease, and the entry route to the infection by the agent may be determinant in its clinical manifestation.

We draw attention to the importance of molecular diagnosis for the identification of Actinobacillus lignieresii, especially in atypical cases of the disease.

Conflict of interest statement.- The authors declare that there are no conflicts of interest. 


\section{REFERENCES}

Anderson K.L., Fairley R.A. \& Duncan D. 1990. Suspected actinobacillosis manifested by facial enlargement in a heifer. J. Am. Vet. Med. Assoc. 197(10):1359-1360. <PMid:2266054>

Andreazza D., Wouters A.T.B., Watanabe T.T.N., Boabaid F.M., Wouters F., Souza F.S., Souza S.O \& Driemeier D. 2013. Caracterização patológica e imunohistoquímica das lesões de actinobacilose em bovinos. Pesq. Vet. Bras. 33(3):305-309. <http://dx.doi.org/10.1590/S0100-736X2013000300005>

Birgel E.H.J., Ollhoff R.D., Benesi F.J., Viana R.B., Schalch U.M., Pacheco J.C.G., Florio W.A.B., Ramos M.C.C \& Biirgel E.H. 1999. Ocorrência de Lechiguana (paniculite fibrogranulomatosa proliferativa focal) em bovino criado no estado de São Paulo. Arqs Inst. Biológico, São Paulo, 66(Supl.):130.

Caffarena R.D., Rabaza A., Casaux L., Rioseco M.M., Schild C.O., Monesiglio C., Fraga M., Giannitti F. \& Riet-Correa F. 2017. Natural lymphatic ("atypical") actinobacillosis in cattle caused by Actinobacillus lignieresii. J. Vet. Diagn. Invest. 30(2):218 -225. <http://dx.doi.org/10.1177/1040638717742621> <PMid:29202671>

Cahalan S.D., Sheridan L., Akers C.R., Lorenz I. \& Cassidy J. 2012. Atypical cutaneous actinobacillosis in young beef cattle. Vet. Rec. 171(15):375. <http://dx.doi.org/10.1136/vr.100906> <PMid:22915684>

Dhand N.K., Sandhu K.S., Singh J. \& Randhawa S.S. 2003. Outbreak of actinobacillosis in dairy cows. Vet. Rec. 153(9):280. <PMid:12974346>

Kasuya K., Manchanayake T., Uenoyama K., Kawa S., Takayama K., Imai N. \& Shibahara T. 2017. Multifocal suppurative granuloma caused by Actinobacillus lignieresii in the peritoneum of a beef steer. J. Vet. Med. Sci. 79(1):65-67. <http://dx.doi.org/10.1292/jvms.16-0402><PMid:27773882>

Ladeira S., Riet-Correa F., Pereira D.B. \& Carter G.R. 1996. Role of Pasteurella granulomatis and Dermatobia hominis in the etiology of lechiguana in catte. Ann. N.Y. Acad. Sci. 791:359-368. <http://dx.doi.org/10.1111/j.1749-6632.1996. tb53543.x> <PMid:8784517>

Margineda C.A., Odriozola E., Moreira A.R., Cantón G., Micheloud J.F., Gardey P., Spetter M. \&. Campero C. M. 2013. Atypical actinobacillosis in bulls in Argentina: granulomatous dermatitis and lymphadenitis. Pesq. Vet. Bras. 33(1):1-4. <http://dx.doi.org/10.1590/S0100-736X2013000100001>

Milne M.H., Barrett D.C., Mellor D.J., Fitzpatrick J.L. \& O'Neill R. 2001. Clinical recognition and treatment of bovine cutaneous actinobacillosis.
Vet. Rec. 148(9):273-274. <http://dx.doi.org/10.1136/vr.148.9.273> <PMid:11292088>

Mondadori A. J., Riet-Correa F., Carter G.R. \&, Mendez M.C. 1994. Actinobacilose em bovinos no Rio Grande do Sul. Ciência Rural. 24(3):571-577 <http://dx.doi.org/10.1590/S0103-84781994000300022>

Peli Agnelo., Spadari A., Romagnoli N., Bettini B., Scarpa F. \& Pietra M. 2009. An atypical case of respiratory actinobacillosis in a cow. J. Vet. Sci. 10(3):265267. <http://dx.doi.org/10.4142/jvs.2009.10.3.265><PMid:19687629>

Relun A., Cesbron N., Bourdeau P., Dorso L., Brement T., Assié S., Christensen H. \& Guatteo R. 2019. Atypical actinobacillosis affecting hind limbs and lungs in a single beef cattle herd. J. Vet. Intern. Med. 33(1):297-301. <http:// dx.doi.org/10.1111/jvim.15387><PMid:30548325>

Riet-Correa F., Méndez M.C., Schild A.L., Ribeiro G.A. \& Almeida S.M. 1992 Bovine focal proliferative fibrogranulomatous panniculitis (lechuguana) associated with Pasteurella granulomatis. Vet. Pathol. 29(2):93-103. <http://dx.doi.org/10.1177/030098589202900201><PMid:1632062>

Rycroft A.N. \& Garside L.H. 2000. Actinobacillus species and their role in animal disease. Vet. J. 159(1):18-36. <http://dx.doi.org/10.1053/ tvjl.1999.0403><PMid:10640409>

Schild A.L., Marques L.S., Coelho A.C.B., Echenique J.Z., Santos B.L., Estima-Silva P. \& Oliveira P.A. 2017. Doenças diagnosticadas pelo Laboratório Regional de Diagnóstico no ano 2016. Bol. Lab. Reg. Diagn. 39:9-26.

Schild A.L., Marques L.S., Echenique J.Z., Lemos B.S. \& Estima-Silva P. 2018. Principais diagnósticos realizados em ruminantes e equinos no Laboratório Regional de Diagnóstico entre 1978-2017. Bol. Lab. Reg. Diagn. 40:35-52.

Staden R. 1996. The Staden sequence analysis package. Mol. Biotechnol. 5(3):233-241.<http://dx.doi.org/10.1007/BF02900361><PMid:8837029>

Tessele B., Martins T.B., Vielmo A. \& Barros C.S.L. 2014. Lesões granulomatosas encontradas em bovinos abatidos para consumo. Pesq. Vet. Bras. 34(8):763769. <http://dx.doi.org/10.1590/S0100-736X2014000800010>

Turni C., Yee S., Epstein V., Jackson B., Li K., Knowles G. \& Blackalla P.J. 2019. Diverse strains of Actinobacillus lignieresii isolated from clinically affected cattle in a geographically restricted area. Austr. Vet. J. 97(11):440-446. <http://dx.doi.org/10.1111/avj.12868><PMid:31475335> 